\title{
Effective breakage of phage $\lambda$ DNA by shearing with ceramic-coated needle of syringe
}

\author{
Hachiro Inokuchi ${ }^{1}$ and Yukio Inokuti ${ }^{2}$ \\ ${ }^{1}$ Department of Biotechnology, National Institute of Technology and Evaluation, Kazusa, \\ Chiba 292-0818 \\ ${ }^{2}$ Steel Research Laboratory, JFE Steel Co., Kawasaki, Chuo, Chiba 260-0835, Japan
}

(Received 12 January 2005, accepted 26 January 2005)

\begin{abstract}
The loss of biological activity of phage $\lambda$ DNA was much greater when the DNA was sheared using a ceramic-coated needle attached to a syringe compared with a conventional stainless steel needle. Inactivation of the biological activity was due to breakage at the middle of the molecule. The thickness of the ceramic-coating was a crucial factor for the breakage. Because approximately the same level of inactivation was observed with a non-coated needle as with thin glass and quartz tubes, it was concluded that the unknown characteristic(s) of the silicon nitride (SiNx) coating itself resulted in the effective breakage of $\lambda$ DNA molecules by shearing force.
\end{abstract}

Key words: ceramic-coated needle, DNA shearing, in vitro packaging system, phage $\lambda$ DNA

It is well known that DNA molecules of high molecular weight are fragile and easily fragmented by hydrodynamic shear. This shearing stress must accordingly be minimized when handling the whole genomes of viruses and microorganisms in genetic engineering.

Recently, the development of a new type of ceramiccoated stainless steel puncture needle has been reported (Mori et al., 2003; Inokuti et al., 2004). This needle has unique chemical and physical capacities, e.g., high electrical resistance, good adhesion and high hardness. The most useful feature of this new needle is its gentleness toward tissues when used clinically to obtain biopsy tissue specimens, as demonstrated by various electron microscopic studies (Inokuti and Mori, 2004; Fukuda and Inokuti, 2004).

In this study, we attempted to use this newly developed needle for handling phage $\lambda$ DNA, expecting that it would also be gentle to DNA macromolecules. The results, however, were completely opposite to our expectations: inactivation of phage $\lambda$ DNA by shearing with the ceramic-coated needle was much greater than by shearing with the conventional stainless needle.

Fig. 1 presents the inactivation curves of phage $\lambda$ DNA obtained by shearing with the syringes. A solution of phage $\lambda$ DNA was aspirated into and pushed out through the two types of needles. In order to make precise comparisons, we constructed an apparatus consisting of two small syringes connected in parallel and attached to a pis-

Edited by Eiichi Ohtsubo

*Corresponding author. E-mail: inokuchi-hachiro@nite.go.jp ton-rod to convert rotary motion obtained using a small motor to reciprocal movement. Thus, we were able to use two syringes for exactly the same time at exactly the same speed. Aliquots of the DNA solution were withdrawn after various numbers of strokes. The samples were then subjected to the in vitro packaging reaction with phage $\lambda$ packaging extract (Hohn, 1979) and assayed by titering the packaged phages on the indicator bacteria. A clear difference between the inactivation by the two types of needles (approximately two orders of magnitude difference after six strokes) was observed. The results were reproducible and convincing. By performing extensive further experiments, we found that the inactivation was dependent on the following factors: (i) concentration of the phage DNA solution, (ii) speed of the stroke, and (iii) caliber of the needle. These factors were predictable based on previous studies (Hershey et al., 1962; Hogness and Simmons, 1964; Yew and Davidson, 1968; Skalka, 1971). The evidence we obtained can be generally summarized as follows: for both kinds of needles, the higher the concentration of DNA, the slower the speed of the stroke, and the wider the caliber of the needle, the less inactivation was observed (data not shown). The most interesting fact we observed was that the breakage of phage DNA was enhanced by ceramic coating.

In order to clarify the features of the inactivated DNA molecules, first of all, the inactivated DNA was subjected to agarose gel electrophoresis. Definite breakage of the DNA was observed in the case of the ceramic-coated needle (Fig. 2 right, lanes 1-4), while a lower level of DNA breakage was observed in the case of the stainless steel 


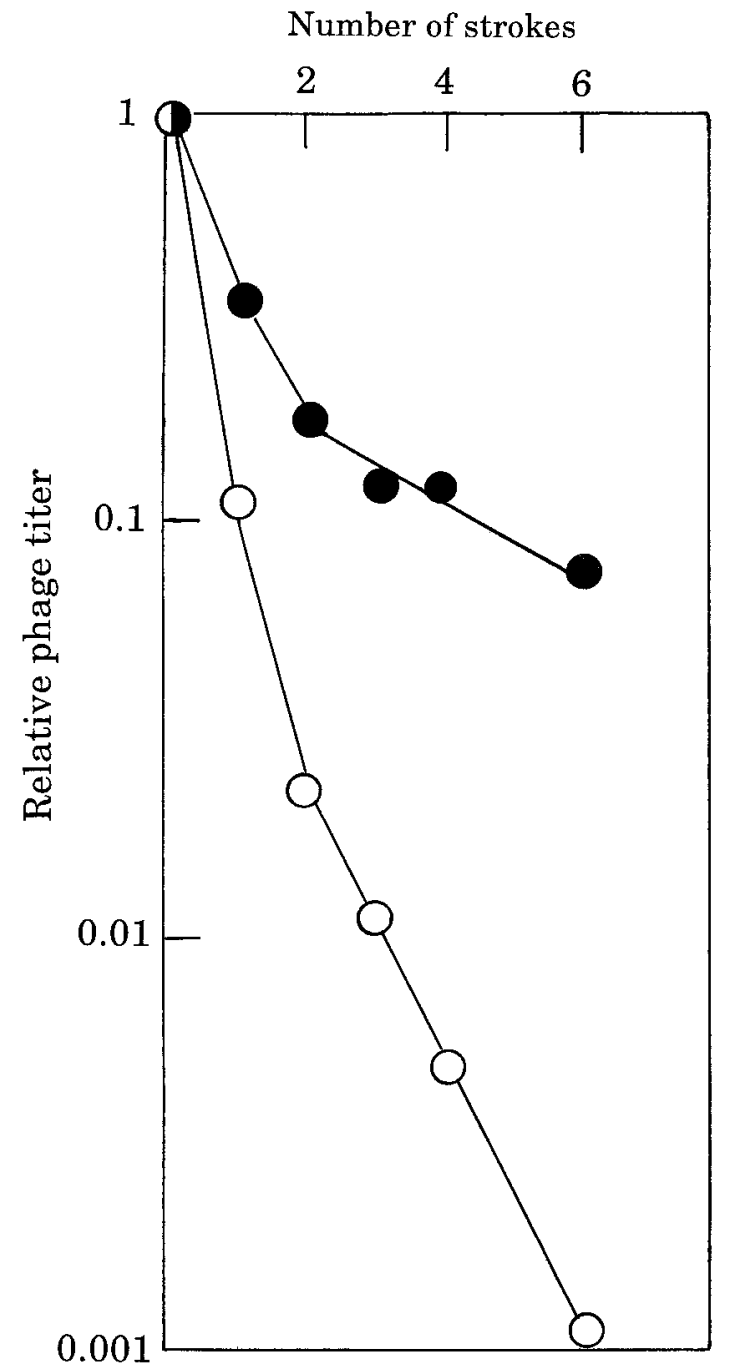

Fig. 1. Inactivation of $\lambda$ DNA by shearing with a ceramiccoated stainless steel needle (open circles) or a conventional stainless steel needle (solid circles) attached to a syringe. Ten micro-liters of $\lambda \mathrm{cI}_{\mathrm{ts} 857} \mathrm{~S}_{\mathrm{am} 7}$ DNA $(0.35 \mu \mathrm{g} / \mu \mathrm{l}$, purchased from Takara Bio Co., Kyoto, Japan) was diluted into $1 \mathrm{ml}$ of $10 \mathrm{mM}$ Tris-HCl (pH 8.0)-1 mM EDTA (TE) buffer, and divided into two 1.5-ml Eppendorf centrifuge tubes. In order to linearize phage $\lambda$ DNA prior to treatment by shearing, the DNA solution was incubated at $75^{\circ} \mathrm{C}$ for 5 minutes and cooled rapidly in an icebath. One-milliliter disposable syringes purchased from Terumo (Tokyo, Japan) were attached to the two types of needles. Needles with or without a $1-\mu \mathrm{m}$ coating that were $0.5 \mathrm{~mm}$ in caliber and $300 \mathrm{~mm}$ long were used. The ceramic-coated needle was a trial product of JFE Steel Co., Steel Research Laboratory (Chiba, Japan). A single round of aspirating and expelling the solution was defined as one stroke and the speed of strokes was expressed by the rotation of the motor (rotations per minute). In this experiment, the speed was set up at 15 rotations per minute (i. e., 4 seconds per stroke). The shearing treatment was performed at room temperature. To determine the biological activity of the treated DNA, $1 \mu \mathrm{l}$ of DNA solution was added to $5 \mu \mathrm{l}$ of in vitro phage $\lambda$ packaging extract purchased from Epicentre (Madison, WI, USA) and incubated 3 hours at $32^{\circ} \mathrm{C}$. After incubation, the titer of produced phages was estimated by the soft agar plating method (Sambrook et al., 1989) using the indicator bacteria BT32 (Inokuchi et al., 1989).

\section{non-coated ceramic-coated}

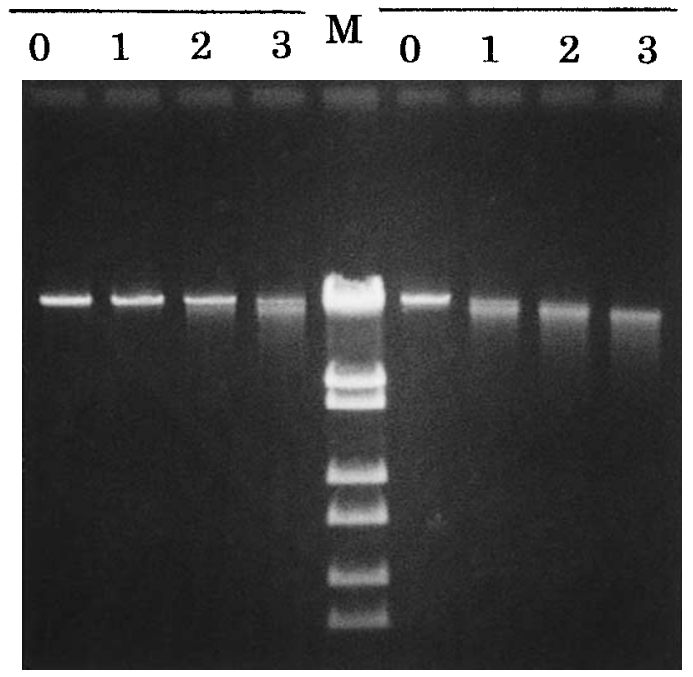

Fig. 2. Agarose gel electrophoresis of the treated lambda phage DNAs. The central lane (M) contains DNA size markers consisting of wild-type lambda DNA digested with restriction enzyme Sty I (purchased from Takara Bio Co., Kyoto, Japan). The sizes of fragments are $19.3(\mathrm{~kb}), 7.7,6.2,3.5,2.7,1.9,1.5$ and 0.9 from top to bottom. 0 - 3 indicates the number of passages through the needle (speed: 15 rotations per minute). The 4 lanes to the left of the size marker lane contain DNA treated with the conventional stainless steel needle, and the right 4 lanes contain DNA treated with the ceramic-coated needle. Fifteen-microliter aliquots of the treated DNA samples were electrophoresed on agarose $\left(0.7 \%\right.$, UltraPure ${ }^{\mathrm{TM}}$ Agarose; Invitrogen Life Technologies, Carisbad, CA, USA) gel, stained with ethidium bromide solution and photographed under ultraviolet light.

needle (Fig. 2 left, lanes 1-4). These results suggest that the loss of biological activity of phage $\lambda$ DNA is due to breakage of the molecules.

It is known that the breakage of $\lambda$ DNA by shearing occurs primarily at the center of the DNA molecule and the point of the breakage is within plus-minus 0.16 molecular lengths of the center of the molecule (Davidson and Szybalski, 1971). In order to identify the point of breakage in this case, we performed polymerase chain reaction (PCR) using as a template the biologically inactive phage DNA after treatment by shearing. The PCR amplification of the central part of the molecule was diminished significantly by dilution of the template DNA (Fig. 3). On the other hand, the amplification of both terminal regions was observed even using the diluted template. From these results, we concluded that the inactivation of $\lambda$ phage DNA molecule caused by shearing with the syringe was initially due to breakage in the central region of the molecule, not breakage at either terminal region.

One of the unique physical properties of the ceramiccoated needle compared with the conventional stainless steel needle is its electrical resistance (Mori et al., 2003). To examine the correlation between the electrical resistance and the inactivation of $\lambda$ DNA, we compared 


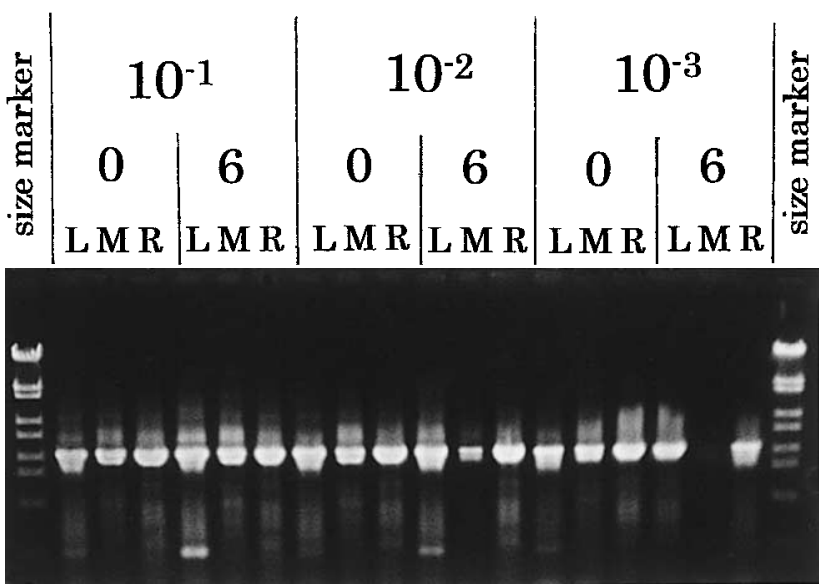

Fig. 3. Agarose gel electrophoresis of PCR products amplified using as template inactivated DNA that had been subjected to shearing by the ceramic-coated syringe-needle. $10^{-1}, 10^{-2}$ and $10^{-3}$ indicate the dilutions of template DNA ( $10^{-1}$ dilution, 350 $\mathrm{pg} / \mu \mathrm{l}$ lambda DNA; $10^{-2}$ dilution, $35 \mathrm{pg} / \mu \mathrm{l} ; 10^{-3}$ dilution, $3.5 \mathrm{pg} /$ $\mu \mathrm{l})$. 0 means no treatment; 6 , shearing with 6 strokes (speed: 15 rotations per minute). L indicates the PCR products from the left terminal region of $\lambda$ DNA [nucleotide positions $1-2024$ (Sanger et al., 1982): Primer Ln-1, 5'-gggCggCgACCTCgCgggTTTTCg-3': Primer Lrev-1, 5'-CAgCgTCTgTTCATCgTCgTggCg-3']; M, the PCR products from the central region [nucleotide positions 22079 - 24142: Primer Mn-1, 5'-CCggTCTgCCTgCAAACAgTACCG-3': Primer Mrv-1, 5'AgCAACgTgTTAgCAgAgCCAAgC-3']; R, the PCR products from the right terminal region [nucleotide positions 46480 - 48449: Primer Rn-1, 5'CgCTTCCAgCggAgTATAAATgCC-3': Primer Rrv-2, 5'-TACATATCACAACgTgCgTggAgg-3']. These primers were custommade products of Qiagen K. K. (Tokyo, Japan). The reaction mixture (total volume $100 \mu \mathrm{l}$ ) for PCR was as follows (with reagents from a kit purchased from Takara Bio Co. Kyoto, Japan): Takara Taq $^{\mathrm{TM}}$ (5 units/ $\left.\mu \mathrm{l}\right), 0.5 \mu \mathrm{l} ; 10 \times$ PCR buffer, $10 \mu \mathrm{l}$; dNTP mixture (2.5 mM each), $8 \mu \mathrm{l}$; primers 1 and 2 (100 pmol each), $10 \mu \mathrm{l}$; template DNA treated by shearing, $10 \mu \mathrm{l}$; sterilized distilled water, up to $100 \mu \mathrm{l}$. The PCR conditions were 35 cycles of $94^{\circ} \mathrm{C}, 30 \mathrm{sec} ; 55^{\circ} \mathrm{C}, 30 \mathrm{sec}$; and $72^{\circ} \mathrm{C}, 1 \mathrm{~min}$. A Gene$\mathrm{Amp}^{\mathrm{R}}$ PCR System 9700 (Applied Biosystem, Foster City, CA., USA) thermal cycler was used. Fifteen microliters of the amplified products were subjected to agarose gel electrophoresis as described in the legend of Fig. 2.

the level of inactivation using needles which had various thicknesses of ceramic-coating film. As shown in Table 1 , a $1-\mu \mathrm{m}$ thick ceramic-coating was necessary to obtain effective inactivation of the phage DNA. We confirmed these results by repeating the experiments using different lots of the test-products.

If the electrical resistance itself affects the efficiency of inactivation, a needle made with glass or quartz may also cause a high rate of inactivation. However, this prediction was not the case, as shown in Table 1. The level of inactivation obtained with thin glass and quartz tubes was almost the same level as that obtained with the noncoated needle. Thus, we concluded that not only the electrical resistance but some yet unidentified characteristic(s) of the new material SiNx used for the coating
Table 1. The effect of the thickness of ceramic coating of the syringe needle and different materials for the needle.

\begin{tabular}{lccc}
\hline \hline $\begin{array}{c}\text { coating }(\mu \mathrm{m}) \\
\text { of materials }\end{array}$ & $\begin{array}{c}\text { electrical } \\
\text { resistance } \\
(\Omega \mathrm{cm})\end{array}$ & $\begin{array}{c}\text { caliber of } \\
\text { needle } \\
(\mathrm{mm})\end{array}$ & $\begin{array}{c}\text { inactivation ratio } \\
\text { after }\end{array}$ \\
\hline no coating & $7.2 \times 10^{-5}$ & 0.5 & 0.063 \\
0.1 & $8.0 \times 10^{5}$ & 0.5 & 0.054 \\
0.2 & $1.2 \times 10^{7}$ & 0.5 & 0.047 \\
0.5 & $5.0 \times 10^{8}$ & 0.5 & 0.019 \\
1.0 & $\infty$ & 0.5 & 0.002 \\
\hline no coating & $7.2 \times 10^{-5}$ & 0.5 & 0.072 \\
ceramic-coating & $\infty$ & 0.5 & 0.001 \\
glass & $\infty$ & 0.5 & 0.055 \\
quartz & $\infty$ & 0.45 & 0.046 \\
\hline
\end{tabular}

Conditions of the treatment and assay are described in the legend for Fig. 1. In this experiment, four syringes connected in parallel were used to equalize the speed of strokes (speed: 15 rotations per minute). The titer of phage with untreated DNA was $2.4 \times 10^{7}$ phages per $\mathrm{ml}$ and this value was taken as 1.00 to calculate the inactivation ratio. The caliber of the needle was measured as follows: The needle was cut out $15 \mathrm{~mm}$ long, and hot-pressed by making up epoxy molding compound together with the cut needle. The specimen thus obtained was mechanically ground and chemically polished, and finally observed using an optical microscope (Nikon Co. Tokyo, Japan). A $0.01 \mathrm{~mm}$ standard scale (epi-photo TME300U/200 provided by Nikon Co.) was used. Electrical resistance was estimated by the four-probe method (Ikeda et al, 1997) using an instrument purchased from Mitsubishi Chemical Co. (Tokyo, Japan). Quartz and glass thin tubes were the products of Nikkato Co. (Tokyo, Japan).

affect the shearing of DNA molecules.

At present, we are not able to explain how the $\mathrm{SiNx}$ coating promotes the shearing of the DNA. However, the SiNx ceramic thin film coated on stainless steel under high plasma density manifests a typical amorphous structure having salt-pepper contrast. This amorphous structure, in contrast to a crystal structure with a regular atomic arrangement, may be able to promote the shearing. Further studies on the mechanism of the effective shearing of DNA molecules using new materials should prove most important. Although the mechanism of the enhanced DNA shearing is not understood yet, this needle may be useful in the field of DNA technology due to its applicability on a small scale and its ease of handling.

\section{REFERENCES}

Davidson, N., and Szybalski, W. (1971) Physical and chemical characteristics of $\lambda$ DNA. In: The bacteriophage $\lambda$ (ed.: A. D. Hershey), pp. 45-82. Cold Spring Harbor Laboratory, Cold Spring Harbor. NY. USA.

Fukuda, H., and Inokuti, Y. (2004) Aspiration biopsy using new ceramic-coated puncture needle. J. Biomed. Mater. Res. 71B, 392-397.

Hershey, A. D., Burgi, E., and Ingraham, L.(1962) Sedimenta- 
tion coefficient and fragility under hydrodynamic shear as measures of molecular weight of the DNA of phage T5. Biophys. J. 2, 423-443.

Hogness, D. H., and Simmons, J. R.(1964) Breakage of $\lambda d g$ DNA: Chemical and genetic characterization of each isolated halfmolecule. J. Mol. Biol. 9, 411-438.

Hohn, E. G. (1979) In vitro packaging of $\lambda$ and cosmid DNA. Methods in Enzymol. 68, 299-309.

Ikeda, T., Suzuki, T., Komatsu, T., and Ota, Y. (1997) Formation of permalloy magnet resistance film by long throw sputtering. Ulvac. Tech. J. 46, 18-25.

Inokuchi, H., Hoben, P., Yamao, F., Ozeki, H., and Söll, D. (1984) Transfer RNA mischarging mediated by a mutant Escherichia coli glutaminyl- tRNA synthetase. Proc. Natl. Acad. Sci. USA 81, 5076-5080.

Inokuti, Y., Oishi, S., Mori, H., and Fukuda, H. (2004) In 2004 International Metallographic Contest. $1^{\text {st }}$ Place Award (Class 6), Jointly IMS \& ASM, USA. Savannah, Georgia. http://www.metallography.com/ims/savannah/winners.htm
Inokuti, Y., and Mori, H. (2004) Development of new patientfriendly therapeutic puncture needle with high insulation and good adhesion. J. Mater. Proc. Tech. in press.

Mori, H., Inokuti, Y., Fukuda, H., and Ebara, M. (2003) Development of person- friendly medical ceramic-coated puncture needles. Materia Japan 42, 151-153.

Sambrook, J., Fritsch, E. F., Maniatis, T., 1989. Bacteriophage lambda vectors. In: Molecular cloning -A laboratory manual (eds. J. Sambrook, E. F. Fritsch and T. Maniatis), pp. 2.12.125. Cold Spring Harbor Laboratory Press, Cold Spring Harbor, NY. USA.

Sanger, F., Coulson, A. R., Hong, G. F., Hill, D. F., and Petersen, G. B. (1982) Nucleotide sequence of bacteriophage $\lambda$ DNA. J. Mol. Biol. 162, 729-773.

Skalka, A. (1971) A method for the breakage of DNA and resolution of the fragments. Methods in Enzymol. 21, 341-350.

Yew, F. F. H., and Davidson, N. (1968) Breakage by hydrodynamic shear of the bonds between cohered ends of $\lambda$-DNA molecules. Biopolymers 6, 659-679. 